\title{
The Moderating Role of CSR Associations on the Link between Brand Awareness and Purchase Intention
}

\author{
Xuan Lam HOANG ${ }^{1}$, Thi Kim Chi NGUYEN², Hoang Mai LY', \\ Thu Thuy LUONG ${ }^{4}$, Thi Thanh Quy NGUYEN ${ }^{5}$
}

Received: April 09, 2020 Revised: April 25, 2020 Accepted: May 07, 2020

\begin{abstract}
This study uses the moderating model to explore the relationships between Corporate Social Responsibility (CSR) associations, brand awareness and consumer purchase intention. Besides investigating the direct effects of CSR associations on brand awareness and consumer purchase intention, this study also focuses on discovering the moderating role of CSR associations on the relationship between brand awareness and consumer purchase intention among Vietnamese students. Adapting scales from previous research, the authors distribute questionnaires to consumers across the country. Then, the validity and reliability are tested via Cronbach's alpha, Exploratory Factor Analysis (EFA) and Confirmatory Factor Analysis (CFA). Moreover, by employing a meta-analytical path analysis with a sample of 686 consumers, the authors show that CSR associations play an important role in shaping purchase intention among Vietnamese consumers regarding the consumption of organic milk products. Also, CSR associations have a strong effect on brand awareness. However, our study shows that purchase intention is not directly affected by brand awareness. In other words, brand awareness does not mediate the relationship between CSR associations and purchase intention. Interestingly, authors show that CSR associations moderate the link between brand awareness and consumer purchase intention. Based on the research, some recommendations are made to companies that produce organic milk products.
\end{abstract}

Keywords : CSR Associations, Brand Awareness, Consumer Purchase Intention

JEL Classification Code: M14, M31, L66

\section{Introduction}

Consumers decide to choose their favorite and familiar brands because of the growing consumer consciousness (Chi et al., 2009). Thus, companies have to entice their consumers

${ }^{1}$ First Author and Corresponding Author. Lecturer, Hanoi University of Business and Technology, Vietnam [Postal Address: 29A, 124 Vinh Tuy Street, Ha Ba Trung District, Hanoi, 100000, Vietnam] Email: hoanglam@utm.edu.vn

${ }^{2}$ Lecturer, Hanoi University of Business and Technology, email: nguyenchihubt@gmail.com

${ }^{3}$ Researcher, Vietnam Institute of Economics, Vietnam Academy of Social Science, email: lymaivkt@gmail.com

${ }^{4}$ Lecturer, Academy of Finance, email: luongthuthuy2001@gmail.com

${ }^{5}$ Lecturer, Trade Union University, email: thanhquy1310@gmail.com

(c) Copyright: The Author(s)

This is an Open Access article distributed under the terms of the Creative Commons Attribution Non-Commercial License (http://Creativecommons.org/licenses/by-nc/4.0/) which permits unrestricted noncommercial use, distribution, and reproduction in any medium, provided the original work is properly cited. to love to buy their products and brands in order to enhance their competitive advantages, and defeat their competitors. Although consumers are willing to buy a product or use a service, brand awareness still plays a crucial role in their purchase decision. When consumers consider the purchase of a product, the brand name, which might come to their minds at once, reflects the high brand awareness of that product (Macdonald \& Sharp, 2000). Consumers' purchase intention and behavior can be affected by a high brand awareness (Dodds et al., 1991; Grewal et al., 1998). This explains why a company with a product enjoying high brand awareness also has high market share as well as better quality evaluation (Chi et al., 2009). Besides, the role of Corporate Social Responsibility (CSR) associations in enhancing the brand awareness and purchase intention has been the subject of some recent research (e.g. Gatti et al., 2012; Mattera et al., 2012; Rivera et al., 2019). Indeed, corporate reputation is determined as a valuable asset that positively affects purchase intention. Consequently, CSR issues are of 
increasing interest and the importance of CSR also has been increasingly stressed (Gatti et al., 2012).

Corporate Social Responsibility is seen as the extent to which enterprises assume responsibilities related to economic, legal, ethical and discretionary perspectives with regard to their stakeholders; it can be perceived as the best tool which, when effectively managed and communicated, can cooperate with the search for separate positioning to encourage consumer reactions (Maignan et al., 1999; Lacey et al., 2015). According to a marketing perspective, CSR and green-washing are two different constructs, but sometimes they get confused. 'CSR involves the proactive integration into the firm's social, environmental or cultural actions of activities that, put into value, are capable of generating positive impacts for the firm and its its stakeholders (e.g. consumers). It is, therefore, much more than a communicative reaction (a social or environmental 'facelift'), as a response to poor brand positioning or an image crisis' (Rivera et al., 2019, p.396).

Although, many empirical studies on the effects of CSR associations on consumer behavior have approached this topic from a number of different angles (Brown \& Dacin, 1997; He \& Li, 2011; Tian et al., 2011), empirical studies on the effects of CSR associations on brand awareness and purchase intention are still few (Wongpitch et al., 2016). Especially, the moderating effect of CSR associations on the link between brand awareness and purchase intention are still unknown. Thus, this study aims to contribute to the existing literature by analyzing: (1) the direct impacts of CSR associations on brand awareness and purchase intention; (2) the direct link between brand awareness and purchase intention; (3) the mediating role of brand awareness in the relationship between CSR associations and purchase intention; and most importantly (4) the moderating effect of CSR associations on the link between brand awareness and purchase intention.

This study is organized as follows: First, literature review, conceptual framework and hypotheses related to the relationship between CSR associations, brand awareness and consumer purchase intention will be described. Second, research methods including data collection, analyses and measures will be presented. Then, the research result will be discussed. Conclusion and recommendations for further research will be proposed in the final part.

\section{Literature Review}

In a globalized market economy, CSR is seen as part of a modern business. The scope and awareness of CSR issues have changed over time. With several decades of CSR research and development, numerous definitions have been proposed by scholars, organizations, business communities and governments all over the world (Doanh \& Gadomska-
Lila, 2020). Indeed, evidence of the attention of the business community in the social perspectives of firm behavior can be discovered from the mid-twentieth century (van Marrewijk, 2003). Then, the conceptual frameworks related to CSR concepts have been very diverse. CSR can be seen as the reflection of a new social deal between firms and society (van Marrewijk, 2003), while it is also understood as a reaction to the pressure of society, which enterprises have to face now (Caroll, 1979). CSR is placed in the strictly philanthropic field by some studies (van Marrewijk, 2003) whereas others perceive it as obligatory (Bowen, 1953; Frederick, 1960). 'CSR involves the conduct of a business so that it is economically profitable, law-abiding, ethical and socially supportive. To be socially responsible... then means that profitability and obedience to the law are foremost conditions to discussing the firm's ethics and the extent to which it supports the society in which it exists with contributions of money, time and talent. Thus, CSR is composed of four parts: economic, legal, ethical and voluntary or philanthropic' (Carroll, 1999, p. 286).

CSR, sometimes referred as corporate ethics, corporate responsibility, and citizenship, is a broad complex concept and continually evolving. In the past, CSR was considered an obligation of the firm to society (Huynh et al., 2020; Nguyen $\& \mathrm{Tu}, 2020$; Smith, 2003). Then, today CSR is a voluntary activity done by organizations in order to bring benefit to workforce and community. It becomes an opportunity to create value and sustainability for business (Bhattacharya et al. 2011). Each company may engage in CSR via various initiatives, the most common ones are doing charity, engaging in environmental project, making positive contributions to local communities, ensuring human rights.

Academic studies related to CSR-consumer binominal has fundamentally concentrated on two perspectives, such as operationalizing the CSR concepts from the point of consumer' insights and analyzing how the CSR perceptions affect the responses of consumers to the firm (Rivera et al., 2019). Following the first view, some studies have investigated the multidimensionality of CSR construct, proposed by Carroll (1979), including economic, legal, ethical, and philanthropic dimensions, and the Sustainable Development Approach-consisting of economic, social and environmental aspects (Alvarado-Herrera et al., 2017). However, Brown \& Dacin (1997) draw a conceptual framework, which is mostly applied to show the dimensions that place CSR as consumer perception to discover its subsequent effects on subject' response (Du et al., 2007).

Regarding the second view, consumer perceptions of CSR change greatly (Lacey et al., 2015). Although it is believed that CSR is fundamentally involved in affective consumer perceptions of the company, it has been presented that CSR programs can have purely cognitive influences and behavior impacts, such as purchase intention and intention 
to recommend firm image to others (Rivera et al., 2019). Moreover, consumers tend to positively accept company' CSR initiatives, however, they were primarily skeptical of them (Ellen et al., 2006; Forehand \& Grier, 2003). When a company shows its social responsibility, it adapts the common reference framework of increasing turnover and maximizing profit, used to examine behavior of company. Through CSR, the company tries to project a personality characterized by altruistic values, so, consumers start a cognitive process of elaboration to obtain guarantees in linking to the company's good faith in its social obligation and guarantees that the method the company is proving itself via CSR programs is consistent with the firm' real values (Rivera et al., 2019). This cognitive process derived from a course of principal judgments in terms of firm's credibility, its reputation between CSR activities, the company's main programs and its brand positioning displayed in advertising campaign, websites as well as social media (Bigné et al., 2012).

A literature review on the impacts of CSR associations on consumer purchase intentions and behaviors shows that there has been little empirical research on this topic (Ellen et al., 2006; Groza et al., 2011; Lee et al., 2010). Recently, some studies have shown that CSR associations are positively related to brand awareness, even to purchase intention (Rivera et al., 2019), but there are still gaps in our understanding about the moderating role of CSR associations in the link between brand awareness and consumer purchase intention. Thus, the conceptual framework was drawn to explore the direct effects of brand awareness and CSR association on purchase intention as well as investigate the moderating role of CSR associations in the correlation between brand awareness and purchase intention among Vietnamese consumers towards buying organic milk products.

Firstly, brand is defined as a 'name, term, sign, symbol, or design, or a combination of them, that is intended to identify the goods and services of one seller or a group of sellers and to differentiate them from those of competitors' (Kotler, 1991, p.442) while brand awareness is specified as the consumer's capacities to identify and recall the brand in various situations, and it also play the important role in consumer's purchase decision (Aaker, 1997). Brand awareness has contributed to brand equity for experienced customers, however, not to a similar level (Prasad \& Dev, 2000; Uslu et al., 2013). Some studies show that brand awareness has direct influence on consumer decisionmaking in that it affects the formation and strength of brand associations (Lin et al., 2015). Consumers intend to purchase a brand with little time and less cognitive effort (Hoyer, 1984). Brand awareness can help consumers recognizing the brand in the different categories of products and affect them to intent or make decision to buy one (Percy \& Rossiter, 1992). Thus, in this study, the effect of brand awareness on consumer purchase intention will be tested.
H1: Brand awareness has positive effect on consumer purchase intention

Secondly, the number of empirical studies of the impacts of CSR associations on consumer purchase intention is still rather few and the models proposed are also very simple, and usually include CSR associations, attitude toward the company, and/or consumer purchase intention (Wongpitch et al., 2016). In Vietnam, the CSR concept is still in the early stage (Doanh \& Gadomska-Lila, 2020) and many consumers are not aware of CSR associations adequately, particularly in ethical and philanthropic degree (Bala \& Yeung, 2009). The lack of understanding can become a barrier to consumer sensitivity to CSR associations and explains why CSR associations cannot be paid attention to when appraising a company and its products (Maignan, 2001). However, the more the consumers understand about CSR associations, the better they are aware of CSR activities (Lee \& Shin, 2010); as a result, those consumers with a higher degree of awareness of CSR are more likely to present positive attitude towards the sponsoring company and its products or services, and a higher level of purchase intention (Tian et al., 2011).

H2: CSR associations have positive effects on consumer purchase intention

Thirdly, some previous studies posit that CSR associations enhance brand awareness (Rivera et al., 2019). Indeed, CSR associations have direct and positive effects on brand awareness, which then influences brand attitude (Aldas et al., 2013). Consumer perception related to CSR associations is singular, being different to brand attribute (Du et al., 2010), that helps to improve awareness by making brand become more memorable and recognizable. CSR not only has a positive impact on consumer brand perception, but it also is seen as a crucial driver of brand evaluation (Holt et al., 2004). Thus, CSR associations can increase brand awareness (Keller, 2003). In other word, consumer perception of CSR associations results in positive brand awareness (Lai et al., 2010). Therefore, the following hypothesis is proposed to test the relationship between CSR associations and consumer's brand awareness of the organic milk products in Vietnam.

H3: CSR associations have positive effects on brand awareness.

Finally, as mentioned, there are very few studies exploring the relationship between CSR associations and consumer purchase intention (Wongpitch et al., 2016; Zahari et al., 2020) and still now, no studies investigate the moderating role of CSR associations in the link between brand awareness and consumer purchase intention. A moderating impact is defined as 'a variable that alters the direction or 
strength of the relation between a predictor and an outcome' (Frazier et al., 2004, p. 116). Thus, besides exploring the direct relationship between CSR associations and purchase intention, this study also discovers the moderating effect of CSR associations in the link between brand awareness and purchase intention among Vietnamese consumers towards buying organic milk products.

H4: CSR associations moderate the link between brand awareness and consumer purchase intention.

Figure 1 shows the conceptual model of this study.

\section{Research Methods}

\subsection{Sample}

The survey is in two parts, based on the purpose of the research, theoretical background and hypotheses (Doanh \& Bernat, 2019a). In the first section, the questions are designed to allow consumers present their viewpoint regarding brand awareness, CSR associations and purchase intention regarding organic milk products. The measures were also adapted from previous studies. In the second section, demographic questions are designed to obtain consumers' information such as gender, age, marital status, educational level and working experiences. 700 questionnaires were directly distributed to consumers across three regions in Vietnam (North, Central and South), as they go shopping. The authors explain clearly the objectives of the research and instruct respondents how to complete questionnaires. Only 686 questionnaires were answered fully, but the number meets enough conditions for further analyses. Demographic information of respondents is presented in Table 1.

The results of descriptive statistics of demographic layouts show that the big proportion of consumers is female, accounting for $61.8 \%$, and $38.2 \%$ consumers are male. In terms of age, just $0.6 \%$ consumers are under 18 years old; most respondents are aged 22 to $30(46.4 \%)$, followed by customers aged from 35 to $50(20.2 \%)$, and from 30 to

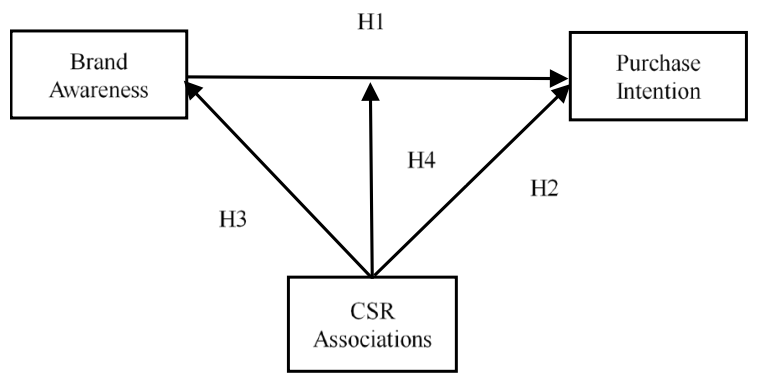

Figure 1: The conceptual model
$35(15.6 \%)$. In addition, $57.4 \%$ of consumers are married and $42.6 \%$ of them are single. Regarding of educational level, the large percentage of consumers had obtained a bachelor degree $(42.2 \%)$, followed by those who have high school, master and $\mathrm{PhD}$ degrees $(35.5 \%, 18.9 \%$ and $3.4 \%$, respectively). Moreover, $43.2 \%$ of consumers have 4-6 years of working experiences and only $14.2 \%$ of them have been working under two years.

\subsection{Analyses}

The authors performed a regression analysis to explore the contributions of brand awareness and CSR associations on consumer purchase intention as well as to examine the moderating effect of CSR associations on the link between brand awareness and purchase intention. Structural equation modelling (SEM) also should be implemented to test the hypothesized relationships and analysis process includes three main steps (Doanh \& Bernat, 2019b). First, Cronbach's alpha and explorative factor analysis (EFA) are employed to evaluate the reliability of variables. Second, confirmatory factor analysis (CFA) is applied to examine the empirical validity of the research model and variables. Finally, the structural equation modelling was then implemented to estimate path

Table 1: Descriptive Statistics of Sample Demographics

\begin{tabular}{|c|c|c|c|}
\hline \multicolumn{2}{|c|}{ Demographic variables } & \multirow{2}{*}{$\frac{F}{262}$} & \multirow{2}{*}{$\frac{\%}{38.2}$} \\
\hline Gonder & Male & & \\
\hline (2) & Female & 424 & 61.8 \\
\hline \multirow{6}{*}{ Age } & Under 18 years old & 4 & 0.6 \\
\hline & From 18 to 22 years old & 103 & 15.0 \\
\hline & From 22 to 30 years old & 318 & 46.4 \\
\hline & From 30 to 35 years old & 107 & 15.6 \\
\hline & From 35 to 50 years old & 139 & 20.2 \\
\hline & Over 50 years old & 15 & 2.2 \\
\hline \multirow{2}{*}{$\begin{array}{l}\text { Marital } \\
\text { status }\end{array}$} & Single & 292 & 42.6 \\
\hline & Married & 394 & 57.4 \\
\hline \multirow{4}{*}{$\begin{array}{l}\text { Educational } \\
\text { level }\end{array}$} & High School & 244 & 35.5 \\
\hline & Bachelor & 289 & 42.2 \\
\hline & Master & 130 & 18.9 \\
\hline & PhD & 23 & 3.4 \\
\hline \multirow{4}{*}{$\begin{array}{l}\text { Working } \\
\text { experience }\end{array}$} & Under 2 years & 97 & 14.2 \\
\hline & From 2 to 4 years & 174 & 25.3 \\
\hline & From 4 to 6 years & 296 & 43.2 \\
\hline & More than 6 years & 119 & 17.3 \\
\hline
\end{tabular}

Note: N=686; F: Frequency; \%: Percent 
coefficients for each proposed links in the research model. In addition, a statistical analysis has been performed using SPSS 22.0 and AMOS 22.0 softwares.

\subsection{Measures}

All scales used in our study were adopted from past research. All constructs are measured on seven-point Likert scales, from strongly disagree to strongly agree. Especially, brand awareness was measured on a 4-items adapted from Rivera et al. (2019), CSR associations were approximated using a 5-item scale adopted from Yoo et al. (2000). Consumer's purchase intention is adapted from the studies of Zeithaml et al. (1996) and Rivera et al. (2019) with four items. All measures were then subjected to exploratory factor analysis (EFA) and confirmatory factor analysis (CFA) for the purpose of scale examining and purification. Particularly:

Brand Awareness-BA (Cronbach's alpha $=0.778$ ), the scale identifies four items: 'It is a well-known brand in its sector' $(0.723)$; 'The brand is appropriate for organic milk products' (0.728); 'I can easily recognize it among others in the sector' (0.703); and 'I can quickly remember its logo' $(0.740)$.

CSR associations-CSR (Cronbach's alpha $=0.910)$, the scale consists of five items: the brand of your preference 'tries to manage economic resources well' (0.897), 'tries to improve the working conditions of collaborators' (0.893), 'tries to contribute to the improvement of the communities in which it works' $(0.879)$, 'tries to promote environmental sustainability' (0.879), and 'tries to behave in an ethically responsible manner' $(0.899)$.

Purchase Intention-PI (Cronbach's alpha $=0.844)$, the scale includes four items: 'I consider my reference brand as my first choice when buying organic milk products' $(0.828)$; 'I will buy my reference brand in my next purchases of organic milk products' (0.793); 'Given equal characteristics with other brand, I prefer to buy my reference brand' (0.798), and ' $I$ do not buy another brand if my reference brand is available in the store' $(0.790)$.

\section{Results and Discussion}

\subsection{Exploratory Factor Analysis (EFA)}

After estimating the reliability of scales by Cronbach's alpha, all 13 items are employed in the exploratory factor analysis (EFA). The results of testing the validity of measures (variables) by the exploratory factor analysis show that $\mathrm{KMO}=0.838$, Sig. $($ Bartlett's Test $)=0.000<$ 0.005 , Initial Eigenvalues $=68.717>50 \%$. Thus, all scales are appropriate for confirmatory factor analysis at the next part. The final results of the exploratory factor analysis are illustrated in Table 2.
Table 2: Exploratory Factor Analysis (EFA)

\begin{tabular}{|l|c|c|c|}
\hline \multirow{2}{*}{\multicolumn{1}{|c|}{ Items }} & \multicolumn{3}{c|}{ Components } \\
\cline { 2 - 4 } & $\mathbf{1}$ & $\mathbf{2}$ & $\mathbf{3}$ \\
\hline CSR3 & 0.886 & & \\
\hline CSR4 & 0.867 & & \\
\hline CSR1 & 0.829 & & \\
\hline CSR2 & 0.828 & & \\
\hline CSR5 & 0.789 & & \\
\hline PI2 & & 0.825 & \\
\hline PI4 & & 0.824 & \\
\hline PI3 & & 0.814 & \\
\hline PI1 & & 0.751 & \\
\hline BA3 & & & 0.806 \\
\hline BA1 & & & 0.775 \\
\hline BA2 & & 0.750 \\
\hline BA4 & & 0.741 \\
\hline $\begin{array}{l}\text { Kaiser-Meyer-Olkin Measure of Sampling } \\
\text { Adequacy (KMO) }\end{array}$ & 0.838 \\
\hline Sig. of Bartlett's Test of Sphericity & 0.000 \\
\hline Cumulative \% & 68.717 \\
\hline
\end{tabular}

Note: $\mathrm{N}=668$

\subsection{Confirmatory Factor Analysis (CFA)}

In order to assess measurement validity, the authors carried out a confirmatory factor analysis (CFA) through applying AMOS 22.0 (Hair et al., 1988). The results generally showed a good level of fit for the measurement models (see Figure 2). Especially, the results of CFA represented a reasonably good level of fit: $\chi^{2}(51)=170.014, p=0.000 . C M I N / d f=3.334<$ 0.5 (Kettinger \& Lee, 1995), CFI $=0.963$, GFI $=0.974$, TLI $=0.960>0.9$, RMSEA $=0.058$ (Bentler \& Bonnett, 1980). Finally, the convergent validity is identified at whole scales.

Moreover, Table 3 shows the results of testing the discriminant validity between variables. The correlation of each couple of variables (r) and standard deviation (SE) are different to 1 (P-value $=0.000<0.005)$. Thus, the discriminant validity between variables is proved.

Table 4 illustrates the results of estimating the measurement validity by CFA. The results represent standardized regression weights $(\lambda)$, composite reliability $(\rho c)$ and average variance extracted ( $\rho v c)$ of all variables.

\subsection{Structural Equation Modelling (SEM) Analysis}

The overall fit statistics of the model without the control variables illustrated an acceptable level of 
Table 3: The results of testing the discriminant validity

\begin{tabular}{|c|c|c|c|c|c|c|c|c|}
\hline \multicolumn{3}{|c|}{ Correlations } & r & 1-r & r2 & SE & CR & P-value \\
\hline PES & $\leftrightarrow$ & EPT & 0.497 & 0.503 & 0.247 & 0.018 & 27.287 & 0.000 \\
\hline PES & $\leftrightarrow$ & ETH & 0.157 & 0.843 & 0.025 & 0.021 & 40.182 & 0.000 \\
\hline PES & $\leftrightarrow$ & EXP & 0.241 & 0.759 & 0.058 & 0.021 & 36.815 & 0.000 \\
\hline
\end{tabular}

Note: N=686; r: correlation; SE: Standard Deviation; CR: Critical Ratios.

Table 4: The results of testing the measurement validity

\begin{tabular}{|c|c|c|c|c|}
\hline Scales & Items & $\lambda$ & $\rho^{c}$ & $\rho^{v c}$ \\
\hline \multicolumn{2}{|c|}{ BA: Brand Awareness } & 0.688 & 0.780 & 0.474 \\
\hline BA4 & \multirow{4}{*}{4} & 0.634 & & \\
\hline BA3 & & 0.751 & & \\
\hline BA2 & & 0.695 & & \\
\hline BA1 & & 0.670 & & \\
\hline \multicolumn{2}{|c|}{ CSR Associations } & 0.801 & 0.900 & 0.645 \\
\hline CSR5 & \multirow{5}{*}{5} & 0.776 & & \\
\hline CSR4 & & 0.844 & & \\
\hline CSR3 & & 0.882 & & \\
\hline CSR2 & & 0.789 & & \\
\hline CSR1 & & 0.715 & & \\
\hline \multicolumn{2}{|c|}{ PI: Purchase Intention } & 0.666 & 0.761 & 0.444 \\
\hline $\mathrm{Pl} 4$ & \multirow{4}{*}{4} & 0.659 & & \\
\hline $\mathrm{PI} 3$ & & 0.640 & & \\
\hline $\mathrm{PI} 2$ & & 0.642 & & \\
\hline $\mathrm{PI} 1$ & & 0.721 & & \\
\hline
\end{tabular}

Note: N=994; $\lambda$ : Standardized Regression Weights; $\rho^{\mathrm{c}}$ : Composite reliability (CR); $\rho^{\mathrm{vc}}$ : Average Variance Extracted (AVE).

fit: $\chi^{2}(50)=177.657, \mathrm{p}=0.000 . \mathrm{CMIN} / \mathrm{df}=3.553<0.5, \mathrm{CFI}$ $=0.962$, GFI $=0.972, \mathrm{TLI}=0.957>0.9, \mathrm{RMSEA}=0.061$. So, the original model was used to test the hypothesized relationships.

A total of four proposed relationships were tested, including three direct effects and one moderating impact. Three of the four hypothesized paths were statistically significant and just one hypothesis was rejected in the direction predicted (see Figure 3 and Table 5). Particularly, CSR associations have the strongest effect on purchase intention $(\beta=0.389$; $p$-value $<0.001)$ ( $\mathrm{H} 2)$. In addition, CSR associations also affect directly on brand awareness $(\beta=0.105 ; \mathrm{p}$-value $<0.001)(\mathrm{H} 3)$. However, there is not enough statistic evidence to show that brand awareness has an effect on purchase intention (p-value > 0.05) (H1). Interestingly, our study shows that the relationship between brand awareness and purchase intention is moderated by

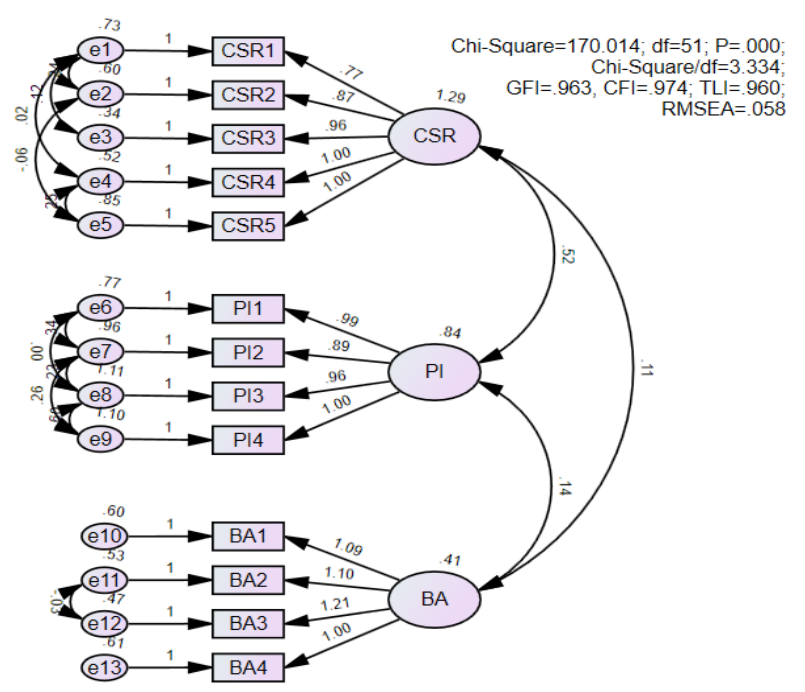

Figure 2: The results of confirmatory factor analysis (unstandardized estimates)

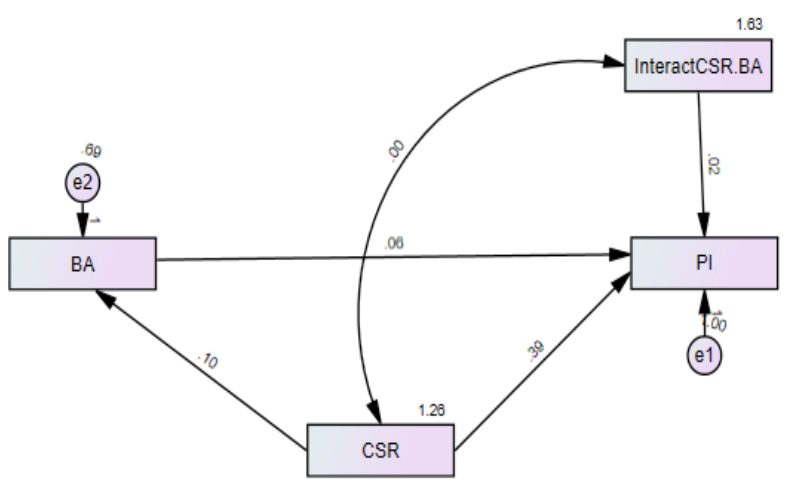

Figure 3: Structural equation modelling (unstandardized estimates)

CSR associations, although the effect level is not high $(\beta=$ 0.020 ; p-value $=0.004<0.01$ ).

\section{Conclusions}

This study is expected to contribute to CSR research and practices. The contribution of our study to CSR literature 
Table 5: The results of testing the research hypotheses

\begin{tabular}{|c|l|c|c|c|c|c|}
\hline \multicolumn{2}{|c|}{ Hypotheses } & Estimate & S.E & C.R & P & Conclusion \\
\hline $\mathrm{H} 1$ & $\mathrm{BA} \rightarrow \mathrm{PI}$ & 0.063 & 0.046 & 1.373 & 0.170 & Rejected \\
\hline $\mathrm{H} 2$ & $\mathrm{CSR} \rightarrow \mathrm{PI}$ & 0.389 & 0.034 & 11.294 & ${ }^{* * *}$ & Rejected \\
\hline $\mathrm{H} 3$ & CSR $\rightarrow \mathrm{BA}$ & 0.105 & 0.124 & 0.036 & ${ }^{* * *}$ & Supported \\
\hline $\mathrm{H} 4$ & Interact(CSR*BA $\rightarrow \mathrm{PI}$ & 0.020 & 0.030 & 2.901 & 0.004 & Supported \\
\hline
\end{tabular}

Note: $N=686 ;{ }^{* * *}<0.001$; S.E: Standard Deviation ; C.R: Critical Ratios.

is two-fold: Firstly, CSR associations have a strong and positive influences on brand awareness and consumer purchase intention, however, our study shows that brand awareness does not affect directly customers purchase intention. In other words, although CSR associations play an important role in shaping both brand awareness and customers' purchase intention, brand awareness does not have direct impact on purchase intention, and it also does not mediate the relationship between CSR associations and consumer purchase intention. Secondly, this study shows that CSR associations not only have direct effect on customer purchase intention, but they moderate the link between brand awareness and consumer purchase intention.

With regard to practices and implications, our research show that companies, which produce organic milk products, should take into account CSR activities to promote consumer's brand awareness as well as purchase intention. On the one hand, the study shows that CSR associations have very strong effects on purchase intention. Thus, consumers are really interested in the information related to CSR practices of firms, and this information can help them recognizing the firm' brand and then entice them to buy the products. On the other hand, CSR associations moderate the relationship between brand awareness and purchase intention. Thus, although brand awareness does not affect directly purchase intention, CSR associations can alter the strength of this relationship. Firms should pay adequate attention on CSR associations to enhance their business advantage.

\section{References}

Aaker, J. L. (1997). Dimensions of Brand Personality. Journal of Marketing Research, 34(3), 347-356.

Aldás, J., Andreu, L., \& Currás, R. (2013). Social responsibility as a creator of brand value: the moderating effect of goal attribution. European Journal of Business Management and Economics, 22, 21-28.

Alvarado-Herrera, A., Bigne, E. Aldas-Manzano, J. \& CurrasPerez, R. (2017). A scale for measuring consumer perception of Corporate Social Responsibility following the Sustainable Development paradigm. Journal of Business Ethics, 140(2), 243-262.
Bala, R. \& Yeung, M. (2009). Chinese consumers' perception of corporate social responsibility (CSR), Journal of Business Ethics, 1(88), 119-132.

Bentler,P.M., \& Bonett, D. G. (1980). Significance tests and goodness of fit in the analysis of covariance structures. Psychological Bulletin, 88(3), 588-606.

Bhattacharya, C. B., Sen, S. \& Korschun, D. (2011). Leverage Corporate Responsibility: the stakeholder route to maximizing business and social value. Cambridge, UK: Cambridge University Press.

Bigné, E., Chumpitaz, R., \& Currás, R. (2010). Alliances between brands and social causes: the influence of company credibility on social responsibility image. Journal of Business Ethics, 96(2), 169-186.

Brown, T. J., \& Dacin, P. (1997). The company and the product. Corporate beliefs and consumer product responses. Journal of Marketing, 61(1), 68-84.

Carroll. (1999). Corporate Social Responsibility: Evolution of a Definitional Construct. Business \& Society, 38 (3), 268-295.

Chi, K. H., Yeh, H. R., \& Yang, Y.T. (2009). The impact of brand awareness on consumer purchase intention: The mediating effect of perceived quality and brand loyalty. The Journal of International Management Studies, 4(1), 135-144.

Dodds, William B., \& Grewal, D. (1991). Effect of price, brand and store information on buyer's product evaluation. Journal of Marketing Research, 28(3), 307-319.

Doanh, D.C., \& Gadomska-Lila, K. (2020). Customers' awareness of corporate social responsibility in Vietnam and Poland: A comparative analysis. Flolia Oeconomica, 1(346), 43-61. https://doi.org/10.18778/0208-6018.346.03

Doanh, D.C., \& Bernat, T. (2019a). Entrepreneurial self-efficacy and intention among Vietnamese students: A meta-analytic path analysis based on the theory of planned behavior. Procedia Computer Science, 159, 2427-2460. https://doi.org/10.1016/j. procs.2019.09.420

Doanh, D. C., Bernat, T. (2019b). Factors related to the intention of starting a business: A study among students in Vietnam. Problemy zarządzania - management issues, 17(6), 133-157. https://doi.org/10.7172/1644-9584.86.8

Du S., Bhattacharya C.B., \& Sen S. (2010). Maximizing business returns to Corporate Social Responsibility (CSR). The role of 
CSR communication. International Journal of Management Reviews, 12(1), 8-19.

Ellen P. S., Webb D. J., \& Mohr L. A. (2006). Building corporate associations: Consumer attributions for corporate socially responsible programs. Journal of the Academy of Marketing Science, 34(2), 147-157.

Frazier, P. A., Tix, A.P. \& Barron, K.E. (2004). Testing moderating and mediator effects in counseling psychology research. Journal of counseling psychology, 51(1), 115-134.

Forehand, M., \& Grier, S. (2003). When is honesty the best policy? The effect of stated company intent on consumer skepticism. Journal of Consumer Psychology, 13(3), 349-356.

Gatti, L., Caruana, A., \& Snehota, I. (2012). The role of corporate social responsibility, perceived quality and corporate reputation on purchase intention: Implication for brand management. Journal of Brand Management, 20(1), 65-76.

Grewal, D., Monroe, K. B., \& Krishnan, R. (1998). The effects of price-comparison advertising on buyers' perceptions of acquisition value, transaction value and behavioral intentions. Journal of Marketing, 62(2), 46-59.

Groza, M., Pronschinske, M.R. \& Walker, M. (2011). Perceived Organizational Motives and Consumer Responses to proactive and reactive CSR. Journal of Business Ethics, 102(4), 639-652.

Hair, J.F.J., Anderson, R.E., Tatham, R.L., \& Black, W.C., (1998). Multivariate Data Analysis (5th ed). Upper Saddle River, New Jersey: Prentice Hall.

He H., \& Li Y. (2011). CSR and service brand. The mediating effect of brand identification and moderating effect of service quality. Journal of Business Ethics, 100, 673-688.

Holt, D. B., Quelch, J. A., \& Taylor, E. L. (2004). How global brands compete. Harvard Business Review, 82, 68-75.

Hoyer, W.D. (1984). An Examination of Consumer Decision Making for a Common Repeat Purchase Product, Journal of Consumer Research, 11(3), 822-829.

Huynh, Q.L. (2020). A triple of Corporate Governance, Social Responsibility and Earnings Management, Journal of Asian Finance, Economics and Business, 7(3), 29-40. https://doi. org/10.13106/jafeb.2020.vol7.no3.29

Keller, K. L. (2003). Brand synthesis: The multidimensionality of brand knowledge. Journal of Consumer Research, 29(4), 595600. DOI: $10.1086 / 346254$

Kettinger, W. J., Lee, C. C., \& Lee, S., 1995. Global Measures of Information Services Quality: A Cross-National Study. Decision Sciences, 26(5), 569-588.

Kotler, P.H. (1991). Marketing management: analysis, planning, and control. (8th ed.) Englewood Cliffs, NJ: Prentice-Hall, Inc.

Lacey, R., Kennett-Hensel, P., \& Manolis, C. (2015). Is corporate social responsibility a motivator or hygiene factor? Insights into its bivalent nature. Journal of the Academy of Marketing Science, 43(3), 315-332.

Lee, K. H., \& Shi, D. (2010), consumers' responses to CSR activities: The linkage between increased awareness and purchase intention. Public Relations Review, 36(2), 193-195.
Lai, C., Chiu, C., Yang, C., \& Pai, D. (2010). The effects of corporate social responsibility on brand performance: The mediating effect of industrial brand equity and corporate reputation. Journal of Business Ethics, 95, 457-469

Lin, A. Y. S., Huang, Y. T., \& Lin, M. K. (2015). Customerbased brand equity: The evidence from China, Contemporary Management Research, 11(1), 75-94.

Macdonald, E. K., \& Sharp, B. M. (2000). Brand awareness effects on consumer decision making for a common, repeat purchase product: A replication. Journal of Business Research, 48, 5-15.

Maignan, I. (2001). Consumer's perception of corporate social responsibilities: A cross-cultural comparison. Journal of Business Ethics, 30(1), 57-72.

Marrera, M., Baena, V. \& Cervino, J. (2012). Analyzing Social Responsibility as a driver of firm's brand awareness. Procedia Social and Behavioral Science, 58, 1121-1130.

Nguyen, T.H., \& Tu, V.B. (2020). Social Responsibility, Organizational Commitment, and Organizational Performance: Food Processing Enterprises in the Mekong River Delta, Journal of Asian Finance, Economics and Business, 7(2), 309316. https://doi.org/10.13106/jafeb.2020.vol7.no2.309

Percy, L., \& Rossiter, J. R. (1992). A model of brand awareness and brand attitude advertising strategies. Psychology \& Marketing, 9, 263-274.

Prasad, K., \& Dev. C.S. (2000). Managing hotel brand equity: a customer-centric framework for assessing performance. Cornell Hotel and Restaurant Administration Quarterly, 41(3), 22-31.

Rivera, J. J., Bigne, E., \& Perez, C., R. (2019). Effects of Corporate Social Responsibility on consumer brand loyalty. Review of Business Management, 21(3), 395-415.

Smith, N. C. (2003). Corporate Social Responsibility: Whether or How? California Management Review, 45(4), 42-76.

Tian, Z., Wang, R., \& Yang, W. (2011). Consumer responses to corporate social responsibility (CSR) in China. Journal of Business Ethics, 101, 197-212.

Uslu, A., Durmuş, B., \& Kolivar, B.K. (2013). Analyzing the brand equity of Turkish airlines services: comparing the Japanese and Turkish perspectives. Social and Behavioral Sciences, 99(6), 446-454.

Yoo, B., Donthu, N., \& Lee, S. (2000). An examination of selected marketing mix elements and brand equity. Journal of the Academy of Marketing Science, 28(2), 195-211.

Zahari, A. R., Esa, E., Rajadurai, J., Azizan, N.A., \& MuhamadTamyez, P. F. (2020). Journal of Asian Finance, Economics and Business, 7(2), 271-280. https://doi.org/10.13106/jafeb.2020. vol7.no2.271

Zeithaml, V. A., Berry, L. L., \& Parasuraman, A. (1996). The behavioral consequences of service quality. Journal of Marketing, 60, 31-46.

Wongpitch, S., Minakan, N., Powpaka, S., \& Laohavichien, T. (2016). Effect of corporate social responsibility motives on purchase intention model: An extension. Kasetsart Journal of social sciences, 37, 30-37. 